\title{
Impact of Radial Score Combined with Advanced Donor Management Protocols on Primary Graft Dysfunction Rates after Heart Transplant in India
}

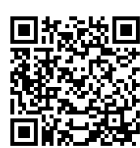

\author{
R Ravi Kumar*, Prabhat Dutta, Pradeep Kumar and Sandeep Attawar \\ Heart Transplant Unit, Gleneagles Global Hospital, India
}

Submission: May 09, 2018; Published: June 06, 2018

*Corresponding author: R Ravi Kumar, Heart Transplant Unit, Gleneagles Global Hospital, Perumbakkam, Chennai, pin 600100, India, Email: ravi63_in@yahoo.com

\section{Opinion}

Primary Graft Dysfunction (PGD) is a significant problem after heart transplant affecting $10-23 \%$ of patients. Some of the non modifiable causes like longer ischeamic time, older donors etc. can be amelerioated using advanced management protocols. Radial score is an internationally accepted Score for measuring Primary graft dysfunction.

We analysed the effect of combining radial scores with improved and advanced donor organ management protocols on primary graft dysfunction rates after heart transplant. Analysis was done retrospectively. There were 23 patients in our study 3 females and 20 males.

On the six Radial Score parameters -Ischeamia time was -135-363mins (average=218mins), RA pressures was 5$28 \mathrm{~mm}$ hg (average $=13 \mathrm{~mm}$ ), recipient age was $12 \mathrm{yrs}-61 \mathrm{yrs}$ (average $=39.3 y r s$ ). Donor age was 13yrs-58yrs (average $=32.6 y r s$ ), Inotrope requirements was 2 days -30 days (average $=-6.9$ days), Diabetes incidence was -9 patients out of 23 .

So the Radial scores for 22 patients were -Score 1 or less in 9 patients, Score 2 in 4 patients, Score 3 in 6 patients and score 4 or above in 4 patients. PVR was less than 4 wood units (WU) in 19 and 4-5WU in 3 patients. All cases had Daily ECHO study post operatively. 3 out of 23 cases were in INTERMACS 3 or below prior to transplant.

Our advanced donor management protocols included on the spot assessment of donor 12 hours before harvesting by dedicated
Organ Management Team, 2D echo assessment (reported by Qualified cardiologist), optimisation of donor parameters in terms of fluid balance, inotropes, electrolytes, blood acid base balance and echo parameters and heamodynamic parameters including filling parameters which was done in consultation with the home hospital cardiac team.

We faced extreme challenges in terms of logistic support and donor hospital assistance for managing the donor in the intensive care unit as well as adverse time pressures from other organ harvesting teams like liver and kidneys. This resulted in a target donor parameter of adequate bi ventricular function, Blood PH $>7.35$, Serum Sodium 130-135, and systolic Blood pressure above 100 prior to harvesting with Urine output of at least $40 \mathrm{ml} / \mathrm{hour}$.

Post Transplant there was 2 cases of primary graft dysfunction noticed 2-4 days after transplant in 23 cases studied. In these cases the radial scores were less than 3 . Two other cases had radial scores of 4 or more but did not develop ant primary graft dysfunction or rejection. We have three deaths out of 23 , due to renal failure and sepsis and all these patients were in INTERMACS 2-3 prior to transplant with radial scores less than 3 in all.

\section{Summary}

We conclude that advanced donor management protocols possibly mitigated the effect of reduced radial scores in heart transplant patients in the Indian context with extreme challenges in terms of logistics regarding donor management and higher mortality in sick cases with higher INTERMACS scores. 

(C) This work is licensed under Creative DOI: 10.19080/JOCCT.2018.11.555804
Your next submission with Juniper Publishers will reach you the below assets

- Quality Editorial service

- Swift Peer Review

- Reprints availability

- E-prints Service

- Manuscript Podcast for convenient understanding

- Global attainment for your research

- Manuscript accessibility in different formats

( Pdf, E-pub, Full Text, Audio)

- Unceasing customer service

Track the below URL for one-step submission https://juniperpublishers.com/online-submission.php 